\title{
ПоЛИТоЛОГИя
}

DOI: $10.17805 /$ ggz.2021.2.4

\section{Неолиберализм как фактор колоссального роста неравенства в мире}

\author{
А. Н. Ильин
}

Омский государственный педагогический университет;

Омский государственный медииинский университет

Идеология и политическая практика неолиберализма широко утвердилась в мире после разрушения сочиалистического лагеря. Капитализм победил, а вместе с ним одержала верх ультрареакционная теория неолиберализма. Данная теория выступает за отход государства от его сочииально полезных функиий. Государство призвано осуществлять большое число социально значимых функиий - от обеспечения общественной безопасности до ограничения бедности и социально-экономического расслоения. Эти функиии нейтрализуются неолиберальным проектом, который стремится отстранить государство от управления обществом и экономикой.

Неолиберальное государство отказывается от регулирования большинства сочиальных и экономических процессов, чтобы они перешли на уровень самоорганизачии. При неолиберальной пассивности государства многие сочиальные слои обрекаются на нищету, а все общество - на тотальный рост неравенства. Автор приводит большое количество статистических данных, которые указывают на рост сочиально-экономического расслоения людей в мировых масштабах.

В статье предпринимается попытка собрать максимальный багаж сведений о растущем неравенстве, чтобы создать полную и достоверную картину реализации этого феномена. Широта статистического охвата и новизна материала являются основными достоинствами статьи. Хотя предлагаемые сведения в некоторых аспектах противоречат друг другу, их совокупность говорит о неуклонной актуализации проблемы неравенства. Обосновывается точка зрения, что колоссальное расслоение является итогом функционирования неолиберального проекта по всему миру.

Ключевые слова: неолиберализм; неравенство; бедность 


\title{
Neoliberalism as a Factor of the Enormous Growth of Inequality in the World
}

\author{
A. N. Ilyin \\ Omsk State Pedagogical University; \\ Omsk State Medical University
}

The ideology and political practice of neoliberalism was widely established in the world after the destruction of the socialist camp. Capitalism won, and the ultra-reactionary theory of neoliberalism prevailed as well. This theory advocates the departure of the state from its socially useful functions. The state is called upon to perform a large number of socially significant functions - from ensuring public safety to limiting poverty and socioeconomic stratification. These functions are neutralized by the neoliberal project, which seeks to remove the state from the management of society and economy.

The neoliberal state refuses to regulate most social and economic processes, so that they move to the level of self-organization. With the neoliberal passivity of the state, many social strata are doomed to poverty, and the entire society is destined to have a total increase in inequality. The author cites a large number of statistical data that indicate the growth of socioeconomic stratification of people on a global scale.

The article attempts to collect the maximum amount of information about the growing inequality in order to create a complete and reliable picture of the implementation of this phenomenon. The scope of statistical coverage and the novelty of the account are the main advantages of the article. Although the mentioned sources contradict each other in some aspects, their totality indicates a steady actualization of the problem of inequality. The author substantiates the point of view that the tremendous stratification is the result of the functioning of the neoliberal project across the globe.

Keywords: neoliberalism; inequality; poverty

\section{ВВЕДЕНИЕ}

Если после Второй мировой войны на Западе был утвержден строй социального капитализма, то начиная с периода правления Р. Рейгана и М. Тэтчер началась волна неолиберализации экономик. И дело не только в перемене для США и Великобритании, когда был нарушен компромисс между капиталом и трудом. С этих времен началась неолиберальная глобализация, формирующая мировое неравенство, делящая мир на новую метрополию и новую периферию. После компрадорского развала Советского Союза неолиберализация мира стремительно усилилась, опираясь в том числе на военную мощь государств центра. 
Неравенство растет в глобальном масштабе, а не только в рамках отдельно взятой страны. В мировой экономике уничтожается как средний класс, так и пролетариат. Массы людей попадают в неустойчивый прекариат. Судьба других — пополнение собой андеркласса.

Китайский ученый Ту Вэймин пишет: «Эйфория, вызванная триумфом капитализма, и ожидание, что либеральная политическая система взглядов будет заимствована повсеместно, довольно быстро закончится. Возникновение “глобальной деревни”, которая в лучшем случае представляет собой воображаемое сообщество, воплощает различия, расслоение и открытую дискриминацию. Наивно надеяться, что экономическая глобализация приведет к равенству положений и возможностей. Мир еще никогда не был так разделен в плане благосостояния, власти и доступа к информации и знаниям. Социальное разделение на всех уровнях, начиная с семьи и заканчивая нацией, вызывает серьезную озабоченность во всем мире. Даже если весь мир поставит целью достижение идеала либеральной демократии, уверенность, что он автоматически станет единственным доминирующим дискурсом в международной политике, является лишь попыткой выдать желаемое за действительное» (Ту Вэймин, 2014: 6).

\section{НЕРАВЕНСТВО ВО ВСЕМИРНОМ МАСШТАБЕ}

В результате неолиберальной глобализации положение среднего слоя ухудшается повсеместно: на периферии и полупериферии капиталистической системы стремительно, в центре - постепенно. Например, в Латинской Америке в 1980-е гг. структурные реформы МВФ привели к обеднению $90 \%$ старого среднего слоя. В конце 1980-х - первой половине 1990-х гг. была сметена немалая часть восточноевропейских средних слоев: в 1989 г. за чертой бедности в Восточной Европе (включая европейскую часть СССР) находились 14 млн человек, а в 1996 г. - 168 млн. Нижняя половина среднего слоя Германии постепенно идет по наклонной; социальный лифт во Франции ходит только вниз. В США с 1973 по 1995 г. реальная зарплата с учетом инфляции снизилась на $17 \%$; личный свободный доход «середняка» в 1977 г. составлял $60 \%$ долга, в 2006 г. - 126 \%. Доля бедных и богатых районов в Штатах увеличивается, а доля районов проживания средних слоев уменьшается (Овчинский, Фурсов, 2009: 77-78).

На практике свободный рынок приводит к жестокой эксплуатации человеческого труда, в том числе детского, и одновременно к росту безработицы. В тех же странах Латинской Америки навязанный сильнейшими транснациональными структурами неолиберальный переход, обеспечив приватизацию, катастрофически увеличил безработицу и нищету; там государства превратились в «ночных сторожей», расписавшись в своем невмешательстве 
сокращением ассигнований на административно-управленческий аппарат, системы социального обеспечения и образования (Визгунова, 2004). В Латинской Америке в 1980-х гг. безработица составила $29 \%$ экономически активного населения, а в 1990-е гг. — 44 \%; тут роль сыграло ее обихаживание структурами типа МВФ, Минфина США и Всемирного банка. С 1960-х гг. снизились глобальные показатели здоровья, продолжительности жизни, выросла детская смертность (Харви, 2007: 208). Без целенаправленного вмешательства ничего само по себе по местам не расстановится, саморегулирование рынка если и происходит, то явно по сценарию неизбежной концентрации капитала и роста имущественного разрыва. Капиталистическая система отклоняется от равновесной траектории экономического роста и политического влияния, отказываясь от саморегуляции на основе концепции равновесия.

50 \% жителей планеты выживают на 1 \% мирового дохода. Если в 2000 г. средний доход на душу населения в США составлял \$180 837 в год, а в Японии \$143 727, то в Индии и Демократической Республике Конго - \$1 тыс. и $\$ 180$ соответственно. К 2008 г. совокупный доход 1100 мировых миллиардеров почти вдвое превышал доход 2,5 млрд живущих за чертой бедности людей. По оценкам ряда экспертов, 300 самых богатых людей Земли сосредоточили в своих руках больше денег, чем находятся в распоряжении 3 млрд самых бедных (Стоун, Кузник, 2014: 717). Ссылаясь на данные бюджетного комитета Конгресса США (!), И. Месарош в 1999 г. писал о том, что совокупный доход $1 \%$ наиболее богатых равен доходу 100 млн беднейших людей Земли, а в конце 1970-х гг. соотношение было 1 \% к 29 млн. При этом в Англии за 19801990-е гг. утроилась и продолжает расти детская бедность (Месарош, Канеллис, 1999: Электронный ресурс). Согласно исследованию Б. Милановича, в 1998 г. доход 1 \% наиболее богатых жителей планеты равнялся доходу 57 \% беднейшего населения, а мировой коэффициент Джини (с его помощью рассчитывается уровень неравенства) вырос до 66 \% (Каллиникос, 2005: 30). Согласно данным за 2013 г., 10 \% людей обладало 86 \% ресурсов, 1 \% из них контролировал 46 \% (Хлопкова, Клементьев, 2018: 145). Также и А. Бадью пишет, что $10 \%$ населения планеты обладает 86 \% всего мирового капитала (Бадью, 2018: 92). Приходящаяся на богатейший 1 \% доля мирового богатства в 2017 г. составила 50,1 \%, бедная половина населения планеты - 3,7 млрд человек - обладает менее чем 1 \% мирового богатства (Акаев, Коротаев, 2019). Соотношение доходов 20 \% самой богатой части населения планеты к 20 \% самой бедной в 1960 г. составляло 30:1, в 1980 - 45:1, в 1989 - 59:1 (Кара-Мурза, 2005: 387), в 1995 г. — 74:1 (Перкинс, 2005: 17; Бирюков, 2015: 59), в 2008 г. - 100:1 (Дробот, 2011: 45).

Вследствие неолиберального империализма уровни зарплат Юга и Севера соотносятся часто как один к десяти или пятнадцати. В 2010 г. из трех 
млрд рабочих в мире около 942 млн были классифицированы Международной организацией труда как «работающие бедные» (т. е. почти каждый третий работник в мире живет менее чем на \$2 в день). Если раньше неравенство определялось в основном классовой принадлежностью, то в наше время оно в немалой степени зависит от места проживания, которое определяет 80 \% глобального неравенства (Лауэсен, Коуп, 2018: Электронный ресурс).

Э. Хобсбаум активно критикует неолиберальную глобализацию, утверждая, что она преуспела в достижении не «золотого века», а ситуации, при которой капитал концентрируется в руках кучки транснациональных корпораций, чей оборот превосходит ВВП многих стран. Автор упрекает глобализацию в космическом взлете экономического и социального неравенства внутри стран и на международном уровне. По Хобсбауму, ежедневный доход половины жителей Земли составляет менее $\$ 2$ в день, а примерно у четверти людей доход менее \$1 в день. На другом полюсе находится суммарное богатство 200 наиболее обеспеченных людей, превосходящее ВВП целой группы стран, в которых проживает более 40 \% населения земного шара. Речь идет не о крупнейших международных корпорациях, а об отдельных личностях. Данная политика, как верно отмечает Хобсбаум, делает все для ослабления и даже ликвидации системы социального обеспечения, которые были гордостью развитых стран. Ссылаясь на подсчеты П. Бэроша и Всемирного банка, Э. Хобсбаум пишет: «...соотношение между долями валового национального продукта на душу населения в богатейших и в беднейших странах выражается следующим образом: 1:19 — в 1950 году, 1:31 — в 1971-м и 1:72 — в середине 90-х годов» (Хобсбаум, 2002: 34).

Похожие цифры приводит А. И. Фурсов: разрыв между богатыми и бедными странами в 1820 г. был 3:1, в 1913 г. — 11:1, в 1973 г. — 44:1, в 1992 г. — 72:1. В 1983 г. годовой доход верхних 500 транснациональных корпораций составил 15 \% глобального, в 2007 г. он достиг 40 \%. Похожим образом обстоит дело с экономическим неравенством между классами и группами. Сегодня $10 \%$ взрослого населения Земли контролируют 85 \% мирового богатства, а на долю нижних 50 \% приходится $1 \%$ богатства. $2 \%$ внутри верхних $10 \%$ владеют $50 \%$ богатства человечества, $8 \%$ - $35 \%$, а самый верхний $1 \%$ 40 \% (Фурсов, 2018а: Электронный ресурс).

Согласно данным ООН, в 2010 г. разрыв между странами с высоким уровнем доходов, где проживал «золотой миллиард» (1004 млн чел., 15,3 \% населения планеты), и странами с низким уровнем доходов, где находится «полюс бедности» (2348 млн чел., 37,2 \% населения Земли), по объему ВВП составил 27 раз, по ВВП на душу населения — 64 раза, по рыночной капитализации активов - 788 раз, по затратам на здравоохранение на душу населения - 115 раз. В 1960 г. различие в доходах между богатейшей пятой частью и 
беднейшей пятой частью населения составляло 30:1, в 1997 г. оно выросло до 74:1 (Симонян, 2018: 19).

3. Бауман приводит много сведений, среди которых следующие: среднедушевой доход в «развивающихся» странах падает; к 1870 г. доход на душу населения в Европе был в 11 раз выше, чем в беднейших странах, а к 1995 г. это превышение достигло 50; состояние 358 «глобальных миллиардеров» равно общему богатству составляющих 45 \% населения планеты 2,3 млрд бедняков; состояние 15 богатейших людей превосходит ВВП всех расположенных к югу от Сахары стран Африки; среди 4,5 млрд жителей третьего мира «трое из каждых пяти лишены доступа к основным элементам инфраструктуры»: питьевой воды, нормального жилья, качественных медицинских услуг (Бауман, 2005: 144). По другим данным, 58 \% жителей планеты живет в бедности (менее чем на \$7,40 в день), их общее состояние меньше состояния нескольких десятков богачей, и только 5 \% нового дохода от роста мировой экономики получают эти 58 \% человечества (Хикел, 2019а: Электронный ресурс). Состояние двухсот наиболее богатых людей выросло более чем вдвое в 19941998 гг., составив свыше \$1 трлн (Харви, 2007: 50). Похоже, что различие в количестве бедных объясняется разными критериями, которыми определяется бедность. Кто-то пишет про планку в $\$ 7,40$ в день, но большинство авторов или вообще не прибегают к какому-то конкретному денежному показателю или используют меньшие цифры: \$2, \$3 и т. д.

Британский социолог указывает на целесообразность в условиях быстро растущего неравенства учитывать не соотношение $10 \%$ самых богатых и $10 \%$ самых бедных, а брать во внимание $1 \%$ (или даже $0,1 \%$ ) наиболее богатых, так как внутри 10 \% богачей тоже происходит серьезное расслоение. Мир пришел к моменту, когда богатые множат свое состояние только потому, что они богатые, а бедные теряют только потому, что они бедные (Бауман, 2015). Вот она - справедливость невидимой руки рынка. Возникла тенденция самовоспроизводства неравенства.

В книге «Идет ли богатство немногих на пользу всем прочим?» 3. Бауман из разных источников приводит множество данных касательно растущей поляризации. Нашим относительно недавно живущим предкам такие цифры представиться не могли даже как возможность. Перечислим некоторые из них:

- богатейшие 20 \% населения потребляют 90 \% произведенных благ;

- 20 богатейших людей мира владеют аналогичным количеством ресурсов, что и беднейший миллиард;

- в 2000 г. на долю самого богатого $1 \%$ взрослых приходилось $40 \%$ глобальных активов, а самые обеспеченные $10 \%$ взрослых владели 85 \% всех богатств мира; 
- во владении нижней половины взрослого населения мира находился $1 \%$ глобальных богатств;

- богатейший $1 \%$ мирового населения сейчас почти в две тыс. раз богаче, чем нижние $50 \%$;

- совокупное состояние самого богатого $1 \%$ американцев составляет \$16,8 трлн, что на \$2 трлн больше, чем совокупное богатство нижних $90 \%$;

- $\quad$ в течение последних трех десятилетий средний доход нижних 50 \% американцев вырос на 6 \%, а доход верхнего 1 \% увеличился на 229 \%;

- более 90 \% прироста ВВП в США, достигнутого после кредитного кризиса 2007 г., была присвоена богатейшим 1 \%;

- средства, принадлежащие 10 богатейшим людям мира, составляют $\$ 2,7$ трлн, что примерно соответствует богатству пятой по величине экономике мира - Франции;

- $\quad$ за последние 30 лет заработки корпоративных руководителей в Британии выросли в 40 раз, а средний размер заработной платы всего лишь утроился(там же: 9, 16-17, 20, 48).

В другой работе 3. Бауман приводит дополнительные данные (некоторые из них противоречат уже приведенным). Жители Европы и США ежегодно тратят \$17 млрд на корма для домашних животных, хотя всего \$19 млрд в год нужно для обеспечения всех голодающих на планете минимальным набором продуктов. В Великобритании доля 1 \% наиболее состоятельных людей в национальном доходе с 1982 по 2008 г. выросла с 6,5 до 13 \%, а высшие менеджеры входящих в расчет лондонского биржевого индекса FTSE100 компаний получают теперь в 133 раза больше их среднего работника (тридцать лет назад этот показатель не превышал 20 раз). В начале $1970-x$ гг. доходы 5 \% самых обеспеченных жителей планеты превышали доходы самых бедных 5 \% в 30 раз, а к 2002 г. — в 114 раз. Половина мировой торговли и более половины прямых иностранных инвестиций обогащают только 22 страны, а на 49 беднейших стран приходится 0,5 \% глобального валового продукта, который равен совокупному доходу трех богатейших людей. 90 \% всего мирового богатства находятся в руках 1 \% (!) жителей планеты (Бауман, 2010: 79, 84). И. Л. Андреев и Л. Н. Назарова называют еще большую цифру: 1 \% населения планеты - верхушка «золотого миллиарда» — распоряжаются 93 \% доходов человечества, а 80 \% сельскохозяйственных земель принадлежат 3 \% населения (Андреев, Назарова, 2016: 100-101).

Дж. Хикел указывает, что абсолютные изменения дохода мирового населения с 1980 по 2016 г. сводятся к тому, что в выигрыше остался 1 \% самых богатых, по сравнению с которыми доход всех остальных едва изменился. Из этого 1 \% чем люди по шкале ближе к 100, тем наиболее серьезно они выиграли. Т. е. чем богаче изначально, тем больше выигрыш. У 60 \% бедного 
населения за 36 лет годовой доход вырос только на \$1 200. Если процентили 70-80 прибавили в два с лишним раза, процентили 80-90 прибавили в четыре раза, то $1 \%$ самых богатых прибавил в 100 раз. Миллионеры прибавили в 14000 раз больше, чем средний человек из бедных 60 \% (Хикел, 2019b: Электронный ресурс).

225 наиболее богатых семей планеты обладают \$1 трлн, что на полтриллиона больше, чем нижняя половина (47 \%) человечества. Францией в 2017 г., как и в 1937 г., правят и экономически владеют 200 семей. В современной Швейцарии верхушка - 3 \% населения - имеет столько же, сколько другие 97 \%; 300 швейцарских сверхбогачей владеют 374 млрд швейцарских франков. В Бразилии 2 \% собственников контролируют 43 \% обрабатываемых земель, а 4,5 млн сельских тружеников вообще не имеют земли. 737 ТНК контролируют 80 \% мировых финансов, из них 147 ТНК владеют 40 \% мировых финансов (Фурсов, 2017: Электронный ресурс).

А. И. Фурсов приводит следующие сведения: по данным компании Wealth-Хв 2017 г., несмотря на кризис, количество миллиардеров в мире увеличилось на 15 \% и достигло рекордного числа - 2754 человек. По сравнению с 2016 г. их общее состояние выросло на 24 \%. По данным Bloomberg Billionaires Index, состояние 24 миллиардеров из России только за январь - июль 2018 г. выросло на \$13 млрд 956 млн (Фурсов, 2018b: 28).

По приводимым У. Беком сведениям, с 1960 по 2000 г. доля самых богатых $20 \%$ населения Земли выросла с 70 до $90 \%$ глобального дохода, а доля 20 \% беднейшего населения снизилась с 2,3 до 1\%. 1,2 млрд людей тратят менее \$1 в день (Бек, 2007: 50). Согласно другим данным, в 1960-1970-е гг. население с доходом менее \$1 в день составляло 200 млн человек, а в начале 1990х гг. оно достигло 2 млрд человек (Субкоманданте Маркос, б/д: Электронный ресурс). Всего 85 человек владеют капиталом, соотносимым с тем, которым обладают 3,6 млрд бедняков (Рябченко, 2016: 89). Согласно другим данным (подсчетам Oxfam), в 2015 г. 62 человека из списка Forbes обладали совокупным состоянием, равным совокупному состоянию 3,6 млрд беднейших людей планеты - половины населения Земли. В 2010 г. аналогичным состоянием обладали 388 богатейших людей планеты. Состояние 62 из них увеличилось с \$542 млрд в 2010 г. до \$1,76 трлн в 2015 г. Митрополит Волоколамский Иларион (Г. В. Алфеев) привел следующие данные: «...совокупное состояние беднейшей половины населения сократилось за тот же пятилетний период на 41 \% (на 1 трлн долл. в абсолютном выражении)» (Иларион ..., 2017: 13; см. также: Lawson, 2016: 11). Ссылаясь на различные исследования, А. А. Бирюков отмечает, что 5 \% самых богатых людей мира в 1993 г. получили средний доход в 114 раз больший, чем 5 \% самых бедных, а в 1988 г. эти показатели различались лишь в 78 раз. В начале XXI в. состояние трех богатейших 
человек превышало доход 48 минимально развитых стран с населением 600 млн жителей (Бирюков, 2015: 59).

Также, обращаясь к разным источникам, П. Ганчев отмечает следующее. В 1970-х гг. разница в доходах на душу населения между 20 \% наиболее бедных и 20 \% самых богатых стран составляла 1:13, в середине 1980-х гг. разница между богатыми странами «Севера» и бедными странами «Юга» достигла 1:61, а в середине 1990-х гг. уже представляла собой соотношение 1:74. В 70х и 80-х гг. ХХ в. только 22 \% глобального богатства принадлежало развивающимся странам, которые составляли 80 \% от всего населения мира. В 1991 г. 85 \% мирового населения получало лишь 15 \% мирового богатства. Более 2,8 млрд людей живут менее чем на \$2 в день, 1,25 млрд человек живут меньше, чем на \$1 в день. За период 1979-1991 г. (когда на смену социальному государству пришел неолиберализм) доходы самых бедных 10 \% населения Земли уменьшились более чем на $20 \%$, а богатых $10 \%$ выросли почти на 70 \%. За 2008 г. (начало кризиса) прибыли мировых финансовых структур составляли 40 \%; к 2011 г. они превысили 70 \%, а в это время нищета углубилась для сотен миллионов людей (Ганчев, 2007, 2012: 65).

Причем за последние четыре десятилетия почти во всех странах росла доля частного имущества, а доля государственной собственности снижалась (Делягин, 2019: 564). Данная приватизационная тенденция подстегивает неравенство и снижает возможности государств с ним бороться.

С. Амин отмечает рост феномена обнищания за последние десятилетия как в странах периферии, так и в развитых странах. Он справедливо объявляет обнищание естественным результатом экспансии империалистического капитализма. Исследователь также пишет, что сумма находящихся в опасном положении трудящихся составляет 40 \% в центрах мировой капиталистической системы и 80 \% на перифериях (Амин, 2007: 54).

\section{НЕСПРАВЕДЛИВОСТЬ ОТЛИЧИЯ ЗАПАДА ОТ ОСТАЛЬНОГО МИРА В КОНТЕКСТЕ НЕРАВЕНСТВА}

Приведем цитату из статьи, опубликованной в 2004 г.: «В США и Канаде проживает $5.2 \%$ населения планеты, но на эти страны приходится примерно 31.5 \% мировых потребительских затрат. Ненамного отстала от лидера и Западная Европа, где проживает 6.4 \% населения Земли, которые потребляют 28.7 \% мировых продуктов. Австралия и Новая Зеландия также относятся к регионам планеты, где доля населения (0.4\%) ниже, чем доля потребляемых ими продуктов в мировом раскладе. На страны Восточной Европы и Бывшего СССР приходится 7.9 \% мирового населения и 3.3 \% потребительских расходов. К наиболее бедным регионам относятся Южная Азия (население 22.4 \%, доля потребляемых продуктов - 2 \%) и Африка южнее Сахары 
(население - $10.9 \%$, доля потребляемых продуктов - $1.2 \%$ )» (На что тратят деньги американцы, 2004: Электронный ресурс).

Как отмечают В. И. Лукьяненко, М. В. Хабаров и А. В. Лукьяненко, «потребление сырья в развивающихся странах в 5 раз меньше среднемирового и составляет всего лишь 10 тонн в расчете на одного человека, а в странах “золотого миллиарда" - в 25 раз больше (250 тонн), причем один американец ежегодно потребляет в 37 раз больше (370 тонн) сырья и материалов по сравнению с жителем развивающейся страны. На промышленно развитые страны ныне приходится около 2/3 мирового потребления стали, свыше 2/3 потребления алюминия, меди, свинца, никеля, олова, цинка и 3/4 объема потребления энергии, которое выросло в 5 раз, в то время как потребление нефти - в 7 раз. Среднестатистический житель промышленно развитой страны потребляет в 10 раз больше стали, в 12 раз больше топлива и в 15 раз больше бумаги, чем житель любой развивающейся страны, причем один американец за год потребляет товаров и услуг в 10 раз больше, чем китаец, и в 30 раз больше, чем индус. $<\ldots>$ Страна, население которой составляет всего лишь $5 \%$ живущих ныне на планете людей, потребляет около 40 \% мировых ресурсов» (Лукьяненко, Хабаров, Лукьяненко, 2009: 154-155).

Страны Запада потребляют около 75 \% всех ресурсов планеты и выбрасывают в окружающую среду примерно такой же процент отходов. Повышению производства для обеспечения возрастающего потребления неумолимо сопутствует рост загрязнения. Н. В. Бекетов публикует следующие цифры: в 60 -е гг. ХХ в. доход обычной развивающейся страны составлял около $12 \%$ от дохода типичной развитой страны, а сейчас этот показатель приближается к $5 \%$, доля богатейших стран в мировом ВВП составляет $86 \%$, доля средних $13 \%$, а доля беднейших — всего лишь 1 \% (Бекетов, 2009: 31). О. И. Шкаратан приводит данные о динамике межстранового неравенства, взятые из работы В. Л. Иноземцева: в начале XIX в. средние доходы в расчете на душу населения в развитом мире превосходили в полтора-три раза показатели развивающихся стран, в середине XX в. - в семь-девять раз, а разрыв, существующий в начале XXI в., составляет 50-75 раз (Шкаратан, 2011: 10; см. также: Иноземцев, 2003). Развитые страны концентрируют в своих руках более 90 \% мирового научного потенциала и контролируют 80 \% рынка высоких технологий, объем которого превышает \$1 трлн (Гезалов, 2012: 92).

При этом идеологи вроде 3. Бжезинского говорят, будто Россия распоряжается слишком большими ресурсами, что им представляется несправедливым. США с их спекулятивной экономикой распоряжаются значительно большими ресурсами, отобранными у других, да еще и за счет других стран. «Вообще особенностью современного мирового хозяйства является то, что производят в нем одни, а потребляют другие» (Дзарасов, 2013: 87), - отмечает 
Р. С. Дзарасов, описавший специфику эксплуатации американским капиталом китайских рабочих. Речь стоит вести о всемирной неолиберальной / неоколониальной эксплуатации. По замечанию В. Ю. Катасонова, «в западных странах на одну единицу национального дохода, созданного собственным трудом, приходится две и более единиц, полученных в результате эксплуатации других народов» (Катасонов, 2012: 218; цит. по: Горелов, 2014: 62). Поэтому всякие домыслы о существовании здорового, хорошего капитализма в западных странах - всего лишь домыслы. Их сторонники утверждают, что Запад создал капитализм с человеческим лицом, но забывают как минимум о двух фактах. Первый - западное богатство создано на костях колоний, а позже неоколоний. Грабеж, устроенный разными способами (далеко не только военным), стал основой развития тех стран, на которые как на свет в оконце смотрят российские либералы. И, превращая Россию в полуколонию в 1990-е гг., они наивно надеялись (или только говорили, что надеялись) построить капитализм с человеческим лицом. Однако такие надежды противоречат практике капиталистического накопления, теории развития капитализма. Мир-система, представляющая собой разделение на метрополию, полупериферию и периферию, остается жить и здравствовать поныне. Поэтому настоящий капитализм - это не США или Великобритания, и даже не Польша; это Мексика или Малайзия. Второй факт - даже в передовых капиталистических странах множится социальное расслоение, растет бедность и социальная напряженность, теряется уверенность в завтрашнем дне и уничтожается «человеческое лицо» системы.

Основные успехи по снижению бедности пришлись на Восточную и Юго-Восточную Азию. Экономический подъем Китая и «азиатских тигров» сопряжен совсем не с неолиберальной экономикой. В этих странах реализовывалась государственная промышленная политика с протекционизмом и госрегулированием. Даже Всемирный банк признал, что в начале «нулевых» успехи в сокращении бедности приходятся на Латинскую Америку и совпадают с функционированием левореформистских и социал-демократических правительств. При этом с 1980 по 2000 г. МВФ и Всемирный банк навязали ряду стран неолиберальные реформы, и за этот период число людей (за пределами Китая), живущих в бедности, выросло на миллиард. В 2009 г. абсолютное число и доля голодающего населения были выше, чем в 1995 г. (Хикел, 2019а: Электронный ресурс). Т. е. рынок усиливало распространение бедности, а госрегулирование ослабляло эту проблему. Приведенные данные опровергают снова и снова высказываемую неолибералами идеологему, согласно которой свободный рынок является фактором(на самом деле несуществующего) сокращения бедности и неравенства.

Мы привели множество сведений из огромного числа источников, тем самым рискуя изрядно наскучить читателю. Но для максимальной полноты 
картины мы должны были это сделать. Конечно, цифры разнятся, в различных источниках встречаются разные оценки, и полного единства тут не может быть. Но факт остается фактом - неуклонно растет поляризация материального состояния, условий жизни и степеней личной свободы. Неолиберальные возгласы о происходящем в результате мировой «демократизации» выравнивании доходов абсолютно нелегитимны, как и нелегитимны сами возгласы о демократизации. Неудивительно, что в наблюдаемых условиях крупнейший бизнес не просто прибирает к рукам огромные богатства и ставит под свой контроль важные сегменты экономики, но и получает серьезную политическую власть, которая, в свою очередь, позволяет ему еще больше обогащаться. Свободный рынок усиливает концентрацию корпоративного капитала в различных областях мировой экономики.

И хотя некоторые приводимые данные об экономическом разрыве противоречат друг другу, есть повод задуматься о масштабах проблемы. Дело не в том, чтобы верить всей противоречивой мозаике сведений (с точки зрения здравого смысла это недопустимо). Важно уяснить, что идет не просто рост, а гиперрост мирового расслоения. Происходящее - позор Системы неолиберализма.

К тому же, как думается, реальная поляризация значительно сильнее, чем та, которая отражается в многочисленных исследованиях. Дело в том, что ученые берут во внимание открытые данные, исследуют рост благосостояния не тех, кто являются наиболее богатыми людьми планеты, а тех, кого принято так называть. Реальные же держатели богатств ни в каких журналах не фигурируют и остаются в тени. Предположительно люди, которым принадлежит Федеральная резервная система США, значительно богаче и влиятельнее тех, кто возглавляет различные публикуемые списки. Но достоверно о них нам ничего не известно.

Чем сильнее неолиберальная глобализация охватывает мир, сплачивает его в своих тисках, тем более он становится расслоенным, неравным в доходах. Как сказал Ж. Деррида, дискурс о правах человека неадекватен, лицемерен и непоследователен, когда остаются в силе рыночные законы, внешние долги, неравенство научно-технического, военного и экономического состояния. В наше время, в период проповеди либеральной демократии, насилие, неравенство, голод, рабское положение, общественное исключение, экономическое угнетение наиболее затрагивают людей (Деррида, 2006: 126).

Вследствие настолько внушительной межстрановой поляризации растет миграция; жители бедных стран в поисках лучшей жизни переселяются туда, где имеется больше возможностей. Когда высококвалифицированные люди мигрируют в больших количествах, они усиливают проблемы для своих стран. Последние сталкиваются с ситуацией «утечки мозгов». Богатые страны не 
только в неоколониальном режиме экономически грабят не могущие себя защитить страны, но и грабят их интеллектуально. Это вносит дополнительную лепту в усиление разрыва между богатыми и бедными странами. В то же время слишком большой поток мигрантов увеличивает проблемы в принимающих странах; растет безработица, усиливается конкуренция. Работодателю выгоднее нанимать имеющих минимум запросов мигрантов, чем своих соотечественников. В итоге сокращаются экономические возможности для местных жителей, осуществляется демпинг зарплат, скукоживается совокупность трудовых прав. Позиция работодателей примерно такова: если местные жители пытаются требовать больших заработков, создавать профсоюзы и отстаивать свои права, мы возьмем на работу непритязательных и ничего не требующих мигрантов, и местные вообще останутся ни с чем. Неолиберальная идеология этот проект поддерживает, распуская болтовню о необходимости открытия границ для рабочей силы, важности принятия мигрантов, нужности межкультурной толерантности. Последняя, конечно, имеет значение, но в данном случае она рассматривается не в контексте гуманизма, а в контексте расширения возможностей наступления капитала на труд. Благодаря мигрантам также увеличивается преступность, особым образом «обогащается» культура. Попутно заметим, что во время существования СССР его республики развивались относительно равным образом; по крайней мере не было сильного экономического разрыва между ними, и потому не имела место столь масштабная миграция из одних республик в другие. Однако после развала СССР миграция на территории СНГ стала усиливаться, отодвигая в сторону трудовые возможности и права местных рабочих.

\section{ЗАКЛЮЧЕНИЕ}

Больше неолиберализма - больше расслоения. Хотя недоверчивый читатель может задаться вопросом: «При чем здесь неолиберализм?». Именно данная идеология и практика предполагает переход на режим жесткой экономии, согласно которому государство перестает выполнять свои функции распределения благ, поддержки малообеспеченных слоев населения, реализации необходимых мер социально-экономической политики. Приближенный к своему абсолюту рынок, доведенный до максимальной крайности, не приемлет каких-либо форм вмешательства государства в экономику, в том числе защиты национального производителя и хотя бы минимального протекционизма. Неолиберализм исходит из того, что в борьбе между капиталом и трудом в руках именно капитала концентрируется максимум прав и возможностей. При господстве данных явлений неравенство определенно стремится к своему росту. И поскольку в мире происходит именно неолиберальная глобализация, неравенство продолжает стремиться вверх. 
В общем, мы наблюдаем огромный массив тенденций, которые просто невозможно списать на незначительный побочный продукт неолиберального капитализма, ставшего глобальным. Конечно, такое списывание возможно, но только в голове не дружелюбного по отношению к реальности человека, которым можно назвать и среднестатистического неолиберального фундаменталиста. Он закрывает глаза на реалии и смотрит исключительно на иллюзии о благом капитализме, продолжая пропагандировать близкие его иллюзорному видению догмы.

Думается, есть огромная доля лицемерия и ханжества в предпринятой на глобальном уровне борьбе с COVID-19, в том широчайшей информационной подпитке, которой правительства разных стран одарили коронавирус. Иронично заметим, что если бы заявления о пандемии вписывались в базу цитирования, то у вируса был бы самый высокий уровень Хирша. И дело не только в том, что по сути борьба превращается в псевдоборьбу, что предпринимаемые меры трансформируются в одно большое ничто в условиях оптимизированной неолиберализмом медицины. Дело еще и в другом... На каждом шагу говорят об опасности вируса, предписывают носить маски и делать тесты. Но ничего не говорится о том, что для многих крайне бедных стран и тех общественных групп внутри богатых обществ (четвертый мир внутри первого), которые влачат нищенское существование, эпидемия ковида - дело далеко не первой важности. Когда вместо уверенности в завтрашнем дне доминирует трудовая неопределенность, когда нет средств на обучение детей, медицинское обслуживание, пропитание, жизнь в целом, проблема COVID-19 кажется малоактуальной.

И получается, что правительства много и самозабвенно вещают об опасности заражения, но ничего не говорят о том, что гораздо более серьезные опасности охватили мир и продолжают его трясти, впиваясь ему в горло своими цепкими клешнями. К ним относится масса явлений, порожденных неудержимой неолиберализацией: распространение безработицы и прекаризация, следующие вместе с утверждением гибкого рынка труда; рост бедности и нищеты; продолжающееся имущественное расслоение и т. д. Поистине была выбрана в качестве мишени только одна проблема, которая для многих людей мира не видна и не ощутима на фоне охвативших их других проблем.

\section{СПИСОК ЛИТЕРАТУРЫ}

Акаев, А. А., Коротаев, А. В. (2019) О начале фазы подъема шестой кондратьевской волны и проблемах глобального устойчивого роста // Век глобализации. № 1 (29). С. 3-17. DOI: 10.30884/vglob/2019.01.01

Амин, С. (2007) Вирус либерализма: перманентная война и американизация мира / пер. с англ. Ш. Нагиба, С. Кастальского. М. : Европа. 168 с. 
Андреев, И. Л., Назарова, Л. Н. (2016) Грозит ли человечеству психический апокалипсис? // Век глобализации. № 3 (19). С. 97-109.

Бадью, А. (2018) Истинная жизнь / пер. с фр. В. Липки. М. : РИПОЛ классик. $176 \mathrm{c.}$

Бауман, 3. (2005) Индивидуализированное общество / пер. с англ. под ред. В. Л. Иноземцева. М. : Логос. 390 с.

Бауман, 3. (2010) От агоры к рынку — и куда потом? // Свободная мысль. № 8 (1615). С. 73-86.

Бауман, 3. (2015) Идет ли богатство немногих на пользу всем прочим? / пер. с англ. Н. Эдельмана. М. : Изд-во Института Гайдара. 105, [2] с.

Бек, У. (2007) Власть и ее оппоненты в эпоху глобализма. Новая всемирно-политическая экономия / пер. с нем. А. Б. Григорьева, В. Д. Седельника ; послесл. В. Г. Федотовой, Н. Н. Федотовой. М. : Прогресс-Традиция ; Изд. дом «Территория будущего». 464 с. (Серия «Университетская библиотека Александра Погорельского»).

Бекетов, Н. В. (2009) Глобализация как процесс формирования информационно-экономического пространства: социальные аспекты развития мировой и национальной экономических систем // Век глобализации. № 1 (3). С. $28-32$.

Бирюков, А. А. (2015) Избыточное человечество? Мальтузианство и марксизм о проблеме «лишних людей» // Вопросы философии. № 12. С. 54-64.

Визгунова, Ю. И. (2004) Безработица в Латинской Америке в условиях неолиберальных реформ // Социологические исследования. № 8 (244). С. 70 77.

Ганчев, П. (2007) Глобализация цивилизации и необходимость новой формы философии // Вопросы философии. № 8. С. 160-165.

Ганчев, П. (2012) Глобальный кризис: необходимость новых принципов, институтов, ценностей // Век глобализации. № 2 (10). С. 62-78.

Гезалов, А. А. (2012) Глобализация как социальная трансформация // Век глобализации. № 1 (9). С. 84-93.

Горелов, А. А. (2014) От мировой колониальной системы до глобального неоколониализма // Век глобализации. № 2 (14). С. 52-64.

Делягин, М. Г. (2019) Конец эпохи: осторожно, двери открываются! Изд. 12-е, перераб. и доп. М. : ИПРОГ ; Книжный мир. Т. 1: Общая теория глобализации. $832 \mathrm{c.}$

Деррида, Ж. (2006) Призраки Маркса. Государство долга, работа скорби и новый интернационал / пер. с франц. Б. Скуратова ; под общ. ред. Д. Новикова. М. : Logos-altera; Ecce homo. 256 c.

Дзарасов, Р. С. (2013) Национальный капитализм: развитие или насаждение отсталости? (окончание) // Альтернативы. № 3 (80). С. 62-99. 
Дробот, Г. А. (2011) Проблема глобального управления в контексте теории международных отношений // Век глобализации. № 2 (8). С. 41-52.

Иларион митрополит Волоколамский (Алфеев, Г. В.) (2017) Православный взгляд на современные проблемы человечества в XXI веке // Вопросы философии. № 4. С. 12-17.

Иноземцев, В. Л. (2003) Глобализация и неравенство: что - причина, что - следствие? // Россия в глобальной политике. № 1. Январь - март. C. $158-175$.

Каллиникос, А. (2005) Антикапиталистический манифест. М. : Праксис. $192 \mathrm{c}$.

Кара-Мурза, С. Г. (2005) Манипуляция сознанием. М. : Эксмо. 832 с.

Катасонов, В. Ю. (2012) Мировая кабала: ограбление по-еврейски. М. : Алгоритм. 382, [1] с.

Лауэсен, Т., Коуп, 3. (2018) Империализм и трансформация стоимости в цену / пер. П. Чикарова [Электронный ресурс] // Lenin Crew. 7 июня. URL: http://lenincrew.com/imperialism-and-the-transformation-of-values-into-prices/ [архивировано в Wayback Machine] (дата обращения: 21.01.2021).

Лукьяненко, В. И., Хабаров, М. В., Лукьяненко, А. В. (2009) Homo consumens - человек потребляющий // Век глобализации. № 2 (4). С. 149-159.

Месарош, И., Канеллис, Э. (1999) Необходимость радикальной альтернативы : интервью [Электронный ресурс] // Скепсис. 25 октября. URL: https:// scepsis.net/library/id_2222.html [архивировано в Wayback Machine] (дата обращения: 21.01.2021).

На что тратят деньги американцы (2004) [Электронный ресурс] // Эксперт-Центр. 15 июля. URL: http://expert.org.ua/obshchestvo/2004/na-chto-tratyatdengi-amerikancy [архивировано в Wayback Machine] (дата обращения: 21.01. 2021).

Овчинский, В. С., Фурсов, А. И. (2009) Передышка для гегемона // Россия в глобальной политике. Т. 7. № 3. С. 69-79.

Перкинс, Д. (2005) Исповедь экономического убийцы. М. : Pretext. 319 c.

Рябченко, Н. П. (2016) Войны: нерешенная проблема человечества // Век глобализации. № 3 (19). С. 85-96.

Симонян, Р. Х. (2018) Кризис либерально-рыночной модели глобализации // Вопросы философии. № 8. С. 16-25. DOI: 10.31857/S004287440000736$\underline{4}$

Стоун, О., Кузник, П. (2014) Нерассказанная история США / пер. с англ. А. Оржицкого, В. Полякова. М. : КоЛибри ; Азбука-Аттикус. 928 с.

Субкоманданте Маркос. (б/д) Семь деталей мировой головоломки / пер. с исп. О. Ясинского [Электронный ресурс] // Скепсис. URL: https://scepsis.net/ 
library/id 575.html [архивировано в Wayback Machine] (дата обращения: 21.01. 2021).

Ту Вэймин. (2014) Разные взгляды на современность: о сущности восточно-азиатской модели современности // Век глобализации. № 1 (13). С. 3 12.

Фурсов, А. И. (2017) Глобализация против планеты. Феномен БРИКС [Электронный ресурс] // Завтра. 29 декабря. URL: https://zavtra.ru/blogs/fenomen_briks [архивировано в Wayback Machine] (дата обращения: 21.01.2021).

Фурсов, А. И. (2018а) Водораздел. Необуржуазия, или Всадники капиталистического апокалипсиса [Электронный ресурс] // Завтра. 11 марта. URL: https://zavtra.ru/blogs/vodorazdel_neoburzhuaziya_ili_vsadniki_kapitalisticheskog o_apokalipsisa [архивировано в Wayback Machine] (дата обращения: 21.01. 2021).

Фурсов, А. И. (2018b) Капитализм, будущее мира и планы закрытых наднациональных структур глобалистов (на примере проблематики обсуждения на Туринской встрече Бильдербергского клуба 7-10 июня 2018 г.) // Моисеевские чтения: Культура и гуманитарные проблемы современной цивилизации : доклады и материалы Всерос. науч. конф. (Москва, 26 мая 2018 г.) / под ред. А. В. Костиной, В. А. Лукова. М. : Изд-во Моск. гуманит. ун-та. 314, [VI] c. С. 14-32. Режим доступа: http://publications.mosgu.ru/index.php/main/catalog/ book/7 [архивировано в Wayback Machine] (дата обращения: 21.01.2021).

Харви, Д. (2007) Краткая история неолиберализма. Актуальное прочтение / пер. с англ. Н. С. Брагиной. М. : Поколение. 288 с.: ил.

Хикел, Дж. (2019а) Бедных в мире становится все меньше? Письмо Стивену Пинкеру (и заодно Биллу Гейтсу) о бедности в мире / пер. с англ. Д. Пономаренко [Электронный ресурс] // Скепсис. 4 февраля. URL: https://scepsis. net/library/id_3878.html [архивировано в Wayback Machine] (дата обращения: 21.01.2021).

Хикел, Дж. (2019b) Насколько велико мировое неравенство, если по правде? / пер. с англ. Д. Пономаренко [Электронный ресурс] // Скепсис. 3 марта. URL: https://scepsis.net/library/id_3913.html [архивировано в Wayback Machine] (дата обращения: 21.01.2021).

Хлопкова, О. В., Клементьев, А. С. (2018) Возможна ли секуляризация ислама? (Взгляд на трансформации религиозности в контексте глобализации) // Век глобализации. № 2 (26). C. 140-149. DOI: 10.30884/vglob/2018.02.11

Хобсбаум, Э. (2002) Мир после 1945 года // Современная Европа. № 1 (9). C. 30-37.

Шкаратан, О. И. (2011) Ожидания и реальность. Социальная мобильность в контексте проблемы равенства шансов // Общественные науки и современность. № 1. С. 5-24. 
Lawson, M. (2016) An economy for the $1 \%$ : How privilege and power in the economy drive extreme inequality and how this can be stopped: Summary. January 18. 12 p. (210 Oxfam Briefing Paper). URL: https://www.oxfam.org/sites/www. oxfam.org/files/file attachments/bp210-economy-one-percent-tax-havens-180116summ-en_0.pdf [архивировано в Wayback Machine] (дата обращения: 21.01. 2021).

Дата поступления: 24.01.2021 г.

\section{REFERENCES}

Akaev, A. A. and Korotaev, A. V. (2019) O nachale fazy pod"ema shestoi kondrat'evskoi volny i problemakh global'nogo ustoichivogo rosta [On the started upward phase of the 6th Kondratieff wave and the problems of global sustainable growth]. Vek globalizatsii, no. 1 (29), pp. 3-17. (In Russ.). DOI: 10.30884/ vglob/2019.01.01

Amin, S. (2007) Virus liberalizma: permanentnaia voina i amerikanizatsiia mira [The liberal virus: Permanent war and the Americanization of the world] / transl. from English by Sh. Nagib and S. Kastalskii. Moscow : Evropa Publ. 168 p. (In Russ.).

Andreev, I. L. and Nazarova, L. N. (2016) Grozit li chelovechestvu psikhicheskii apokalipsis? [Does mental apocalypse threaten mankind?]. Vek globalizatsii, no. 3 (19), pp. 97-109. (In Russ.).

Badiou, A. (2018) Istinnaia zhizn' [The true life / La vraie vie] / transl. from French by V. Lipka. Moscow : RIPOL classic Publ. 176 p. (In Russ.).

Bauman, Z. (2005) Individualizirovannoe obshchestvo [The individualized society] / transl. from English ed. by V. L. Inozemtsev. Moscow : Logos Publ. 390 p. (In Russ.).

Bauman, Z. (2010) Ot agory k rynku - i kuda potom? [From agora to the marketplace, and whereto from here?]. Svobodnaia mysl', no. 8 (1615), pp. 73-86. (In Russ.).

Bauman, Z. (2015) Idet li bogatstvo nemnogikh na pol'zu vsem prochim? [Does the richness of the few benefit us all?] / transl. from English by N. Edelman. Moscow : Publ. House of Gaidar Institute. 105, [2] p. (In Russ.).

Beck, U. (2007) Vlast' i ee opponenty v epokhu globalizma. Novaia vsemirnopoliticheskaia ekonomiia [Power in the global age: A new global political economy / Macht und Gegenmacht im globalen Zeitalter. Neue weltpolitische Ökonomie] / transl. from German by A. B. Grigoriev and V. D. Sedelnik ; afterword by V. G. Fedotova and N. N. Fedotova. Moscow : Progress-Traditsiia Publ. ; Publ. House "Territoriia budushchego". 464 p. (Seriia «Universitetskaia biblioteka Aleksandra Pogorel'skogo» / Series “Aleksander Pogorelsky's University Library”). (In Russ.). 
Beketov, N. V. (2009) Globalizatsiia kak protsess formirovaniia informatsionno-ekonomicheskogo prostranstva: sotsial'nye aspekty razvitia mirovoi i natsional'noi ekonomicheskikh system [Globalization as the process of the informational-economic space organization: Social aspects of the development of the world and national economic systems]. Vek globalizatsii, no. 1 (3), pp. 28-32. (In Russ.).

Biriukov, A. A. (2015) Izbytochnoe chelovechestvo? Mal'tuzianstvo i marksizm o probleme «lishnikh liudei» [A surplus humanity? Malthusianism and Marxism concerning the problem of "extra people"]. Voprosy filosofii, no. 12, pp. 54-64. (In Russ.).

Vizgunova, Yu. I. (2004) Bezrabotitsa v Latinskoi Amerike v usloviiakh neoliberal'nykh reform [Unemployment in Latin America during neo-liberal reforms]. Sotsiologicheskie issledovaniia, no. 8 (244), pp. 70-77. (In Russ.).

Ganchev, P. (2007) Globalizatsiia tsivilizatsii i neobkhodimost' novoi formy filosofii [Globalization of civilization and the need for a new form of philosophy]. Voprosy filosofii, no. 8, pp. 160-165. (In Russ.).

Ganchev, P. (2012) Global'nyi krizis: neobkhodimost' novykh printsipov, institutov, tsennostei [The global crisis: The need for new principles, institutions, and values]. Vek globalizatsii, no. 2 (10), pp. 62-78. (In Russ.).

Gezalov, A. A. (2012) Globalizatsiia kak sotsial'naia transformatsiia [Globalization as a social transformation]. Vek globalizatsii, no. 1 (9), pp. 84-93. (In Russ.).

Gorelov, A. A. (2014) Ot mirovoi kolonial'noi sistemy do global'nogo neokolonializma [From the world colonial system to global neocolonialism]. Vek globalizatsii, no. 2 (14), pp. 52-64. (In Russ.).

Delyagin, M. G. (2019) Konets epokhi: ostorozhno, dveri otkryvaiutsia! [The end of the age: Watch out, the doors are opening!]. 12th edn., revised and supplemented. Moscow : IPROG Publ. ; Knizhnyi mir Publ. Vol. 1: Obshchaia teoriia globalizatsii [General theory of globalization]. 832 p. (In Russ.).

Derrida, J. (2006) Prizraki Marksa. Gosudarstvo dolga, rabota skorbi i novyi internatsional [Specters of Marx: The state of the debt, the work of mourning and the new International / Spectres de Marx: l'état de la dette, le travail du deuil et la nouvelle Internationale] / transl. from French by B. Skuratov; ed. by D. Novikov. Moscow : Logos-altera Publ. ; Ecce homo Publ. 256 p. (In Russ.).

Dzarasov, R. S. (2013) Natsional'nyi kapitalizm: razvitie ili nasazhdenie otstalosti? (okonchanie) [National capitalism: Development or inculcation of backwardness? (the ending)]. Al'ternativy, no. 3 (80), pp. 62-99. (In Russ.).

Drobot, G. A. (2011) Problema global'nogo upravleniia v kontekste teorii mezhdunarodnykh otnoshenii [The problem of global governance in the context of the theory of international relations]. Vek globalizatsii, no. 2 (8), pp. 41-52. (In Russ.). 
Ilarion mitropolit Volokolamskii (Alfeev, G. V.) (2017) Pravoslavnyi vzgliad na sovremennye problemy chelovechestva $\mathrm{v}$ XXI veke [Orthodox viewpoint on problems facing humanity in the 21st century]. Voprosy filosofii, no. 4, pp. 12-17. (In Russ.).

Inozemtsev, V. L. (2003) Globalizatsiia i neravenstvo: chto - prichina, chto - sledstvie? [Globalization and inequality: What is the cause, what is the effect?]. Rossiia v global'noi politike, no. 1, January - March, pp. 158-175. (In Russ.).

Callinicos, A. (2005) Antikapitalisticheskii manifest [An anti-capitalist manifesto]. Moscow : Praksis Publ. 192 p. (In Russ.).

Kara-Murza, S. G. (2005) Manipuliatsiia soznaniem [Manipulation of consciousness]. Moscow : Eksmo Publ. 832 p. (In Russ.).

Katasonov, V. Yu. (2012) Mirovaia kabala: ograblenie po-evreiski [World cabala: Robbery in a Jewish way]. Moscow : Algoritm Publ. 382, [1] p. (In Russ.).

Lauesen, T. and Cope, Z. (2018) Imperializm i transformatsiia stoimosti v tsenu [Imperialism and the transformation of values into prices] / transl. by P. Chikarov. Lenin Crew, June 7. [online] Available at: http://lenincrew.com/imperialismand-the-transformation-of-values-into-prices/ [archived in Wayback Machine] (accessed 21.01.2021). (In Russ.).

Lukianenko, V. I., Khabarov, M. V. and Lukianenko, A. V. (2009) Homo consumens - chelovek potrebliaiushchii [Homo consumens - a consuming man]. Vek globalizatsii, no. 2 (4), pp. 149-159. (In Russ.).

Mészáros, I. and Kanellis, Elias (1999) Neobkhodimost' radikal'noi al'ternativy [The need for a radical alternative] : An interview. Skepsis, October 25. [online] Available at: https://scepsis.net/library/id 2222.html [archived in Wayback Machine] (accessed 21.01.2021). (In Russ.).

$\mathrm{Na}$ chto tratiat den'gi amerikantsy [What Americans spend their money on]. (2004) Ekspert-Tsentr, July 15. [online] Available at: http://expert.org.ua/obshchestvo/2004/na-chto-tratyat-dengi-amerikancy [archived in Wayback Machine] (accessed 21.01.2021). (In Russ.).

Ovchinskii, V. S. and Fursov, A. I. (2009) Peredyshka dlia gegemona [Respite for the hegemon]. Rossiia v global'noi politike, vol. 7, no. 3, pp. 69-79. (In Russ.).

Perkins, J. (2005) Ispoved' ekonomicheskogo ubiitsy [Confessions of an economic hit man]. Moscow : Pretext Publ. 319 p. (In Russ.).

Ryabchenko, N. P. (2016) Voiny: nereshennaia problema chelovechestva [Wars: Unresolved problem of mankind]. Vek globalizatsii, no. 3 (19), pp. 85-96. (In Russ.).

Simonyan, R. Kh. (2018) Krizis liberal'no-rynochnoi modeli globalizatsii [Crisis of liberal-market model of globalization]. Voprosy filosofii, no. 8, pp. 16-25. (In Russ.). DOI: 10.31857/S004287440000736-4 
Stone, O. and Kuznick, P. (2014) Nerasskazannaia istoriia SShA [The untold history of the united states] / transl. from English by A. Orzhitskii and V. Poliakov. Moscow : KoLibri Publ. ; Azbuka-Attikus Publ. 928 p. (In Russ.).

Subcomandante Marcos. (s.d.) Sem' detalei mirovoi golovolomki [Seven loose pieces of the global jigsaw puzzle / Siete piezas sueltas del rompecabezas mundial] / transl. from Spanish by O. Iasinskii. Skepsis [online] Available at: https://scepsis.net/library/id 575.html [archived in Wayback Machine] (accessed 21.01.2021). (In Russ.).

Tu Wei-Ming. (2014) Raznye vzgliady na sovremennost': o sushchnosti vostochno-aziatskoi modeli sovremennosti [Multiple modernities: A preliminary inquiry into the implications of east Asian modernity]. Vek globalizatsii, no. 1 (13), pp. 3-12. (In Russ.).

Fursov, A. I. (2017) Globalizatsiia protiv planety. Fenomen BRIKS [Globalization versus the planet. The BRICS phenomenon]. Zavtra, December 29. [online] Available at: https://zavtra.ru/blogs/fenomen_briks [archived in Wayback Machine] (accessed 21.01.2021). (In Russ.).

Fursov, A. I. (2018a) Vodorazdel. Neoburzhuaziia, ili Vsadniki kapitalisticheskogo apokalipsisa [Watershed. The neo-bourgeoisie, or the Horsemen of the capitalist apocalypse]. Zavtra, March 11. [online] Available at: https://zavtra.ru/ blogs/vodorazdel neoburzhuaziya_ili_vsadniki kapitalisticheskogo apokalipsisa [archived in Wayback Machine] (accessed 21.01.2021). (In Russ.).

Fursov, A. I. (2018b) Kapitalizm, budushchee mira i plany zakrytykh nadnatsional'nykh struktur globalistov (na primere problematiki obsuzhdeniia na Turinskoi vstreche Bil'derbergskogo kluba 7-10 iiunia 2018 g.) [Capitalism, the future of the world and plans of closed supranational structures of globalists (The case of the issues discussed at the meeting of the Bilderberg Club in Turin on June 7-10, 2018)]. In: Moiseevskie chteniia: Kul'tura i gumanitarnye problemy sovremennoi tsivilizatsii [Moiseev Readings: Culture and humanitarian problems of modern civilization] : Proceedings of the All-Russian conference (Moscow, May 26, 2018) / ed. by A. V. Kostina and V. A. Lukov. Moscow : Moscow University for the Humanities. 314, [VI] p. Pp. 14-32. Available at: http://publications.mosgu.ru/index.php/main/catalog/book/7 [archived in Wayback Machine] (accessed 21.01. 2021). (In Russ.).

Harvey, D. (2007) Kratkaia istoriia neoliberalizma. Aktual'noe prochtenie [A brief history of neoliberalism] / transl. from English by N. S. Bragina. Moscow : Pokolenie Publ. 288 p.: ill. (In Russ.).

Hickel, J. (2019a) Bednykh v mire stanovitsia vse men'she? Pis'mo Stivenu Pinkeru (i zaodno Billu Geitsu) o bednosti v mire [A letter to Steven Pinker (and Bill Gates, for that matter) about global poverty] / transl. from English by D. 
Ponomarenko. Skepsis, February 4. [online] Available at: https://scepsis.net/library/ id 3878.html [archived in Wayback Machine] (accessed 21.01.2021). (In Russ.).

Hickel, J. (2019b) Naskol'ko veliko mirovoe neravenstvo, esli po pravde? [How bad is global inequality, really?] / transl. from English by D. Ponomarenko. Skepsis, March 3. [online] Available at: https://scepsis.net/library/id_3913.html [archived in Wayback Machine] (accessed 21.01.2021). (In Russ.).

Khlopkova, O. V. and Klementiev, A. S. (2018) Vozmozhna li sekuliarizatsiia islama? (Vzgliad na transformatsii religioznosti v kontekste globalizatsii) [Is the secularization of Islam possible? (A view on the transformation of religiosity in the context of globalization)]. Vek globalizatsii, no. 2 (26), pp. 140-149. (In Russ.). DOI: $10.30884 / \mathrm{vglob} / 2018.02 .11$

Hobsbawm, E. (2002) Mir posle 1945 goda [The world after 1945]. Sovremennaia Evropa, no. 1 (9), pp. 30-37. (In Russ.).

Shkaratan, O. I. (2011) Ozhidaniia i real'nost'. Sotsial'naia mobil'nost' v kontekste problemy ravenstva shansov [Expectations and reality. Social mobility in the context of the problem of equality of chances]. Obshchestvennye nauki i sovremennost', no. 1, pp. 5-24. (In Russ.).

Lawson, M. (2016) An economy for the 1\%: How privilege and power in the economy drive extreme inequality and how this can be stopped: Summary. January 18. 12 p. (210 Oxfam Briefing Paper). Available at: https://www.oxfam.org/ sites/www.oxfam.org/files/file_attachments/bp210-economy-one-percent-tax-have ns-180116-summ-en_0.pdf [archived in Wayback Machine] (accessed 21.01.2021). Submission date: 24.01.2021.

Ильин Алексей Николаевич - кандидат философских наук, доцент кафедры практической психологии Омского государственного педагогического университета, доцент кафедры философии и социально-гуманитарных наук Омского государственного медицинского университета. Адрес: 644043, Россия, г. Омск, ул. Партизанская 4а, ауд. 117. Эл. адрес: $\underline{\text { ilin1983@yandex.ru }}$

ILYIN, Alexey Nikolaevich, Candidate of Philosophy, Associate Professor, Department of Practical Psychology, Omsk State Pedagogical University; Associate Professor, Department of Philosophy, Social Sciences and Humanities, Omsk State Medical University. Postal address: Aud. 117, 4a Partizanskaya St., 644043 Omsk, Russian Federation. E-mail: ilin1983@yandex.ru

Caŭm aвmopa: $\underline{\text { http://ilinalexey.ru }}$ 
Для цитирования:

Ильин А. Н. Неолиберализм как фактор колоссального роста неравенства в мире [Электронный ресурс] // Горизонты гуманитарного знания. 2021. № 2. C. 54-76. URL: https://journals.mosgu.ru/ggz/article/view/1445 (дата обращения: дд.мм.гггг). DOI: 10.17805/ggz.2021.2.4 